\title{
TINJUAN YURIDIS TERHADAP KEDUDUKAN KPK DAN KEJAKSAAN SEBAGAI LEMBAGA INDEPENDEN DALAM PERSPEKTIF HUKUM TATA NEGARA
}

\author{
Oleh : \\ Happy Trizna Wijaya* \\ *Fakultas Hukum, Universitas Gresik \\ Email : Bebek_Cepat@yahoo.co.id
}

\begin{abstract}
ABSTRAK
Karya tulis ilmiah ini merupakan uraian argumentasi hukum yang didasarkan pada peraturan perundang-undangan, asas-asas maupun teori hukum. Penelitian yuridis normatif untuk membedah kedudukan KPK dan Kejaksaan sebagai lembaga independen berdasarkan undang-undang pembentuknya serta sistem politik Indonesia. Adapun UU No.16 Tahun 2004 dan UU No. 19 Tahun 2019 merupakan dasar hukum pembentuk lembaga tersebut. Arah pandang yang dipilih untuk mengetahui kejelasan dan kepastian kedudukan kedua lembaga independen tersebut. Hal ini penting untuk diketahui agar kewenangan dan tugas penuntutan tindak pidana korupsi antar kedua lembaga tersebut lebih tegas dan tidak saling tumpang tindih. Pemahaman secara komprehensif ini sebagai upaya mewujudkan sistem politik Indonesia yang ideal.
\end{abstract}

Kata Kunci : Lembaga Independen, Kedudukan, Kejaksaan, KPK.

\section{PENDAHULUAN}

Indonesia sebagai negara hukum yang diatur dalam Pasal 1 ayat (3) konstitusi, dalam maknanya menegaskan bahwa penyelenggaraan pemerintahan, ketatanegaraan, kehidupan bernegara dan bermasyarakat harus berdasarkan pada hukum. Sehingga harapan yang ingin diwujudkan dalam negara hukum salah satunya adalah keteraturan, sebab dengan menggunakan hukum mampu mengatur segala bidang agar muncul keteraturan dalam implementasinya. Kemudian untuk membentuk suatu negara hukum diperlukan instrumen hukum, lembaga legislatif, eksekutif dan yudikatif. Akan tetapi dengan perkembangan hukum di Indonesia, muncul lembaga independen.

Dalam artian independen disini terdapat lembaga, badan dan komisi negara, adapun yang melatar-belakangi adalah upaya demokratisasi pada lembaga-lembaga yang melaksanakan

${ }^{1}$ Hendra Nurtjahjo, Lembaga, Badan, dan Komisi Negara Independen (State Auxiliary Agencies) di Indonesia: Tinjauan Hukum Tata Negara, Jurnal Hukum dan Pembangunan, Vol. 35 No. 3, 2005, hlm. 280. fungsinya untuk menyelenggarakan pemerintahaan. ${ }^{1}$ Contoh lembaga independen dalam kaitannya fungsi yudikatif dan eksekutif adalah Komisi Pemberantasan Korupsi (KPK) dan Kejaksaan. Kedua lembaga independen ini memiliki fungsi yang sama, persamaan terdapat pada fungsi dan tugas penuntutan tindak pidana korupsi.

KPK didirikan pada tahun 2003 melalui UU No. 30 Tahun 2002 tentang Komisi Pemberantasan Tindak Pidana Korupsi. Pembentukan KPK disebabkan ada urgensi yang harus diperhatikan oleh pemerintah dan legislatif dalam upaya pemberantasan korupsi. Amanat pembentukan komisi ini berada pada Pasal 43 UU No. 31 Tahun 1999 tentang Pemberantasan Tindak Pidana Korupsi. ${ }^{2}$ Sehingga urgensi pembentukan komisi ini sudah sejak tahun 1999 namun baru dapat disahkan pembentukanya pada tahun 2003. Sekilas pandang tentang KPK

\footnotetext{
${ }^{2}$ Bintara Sura Priambada, Eksistensi KPK Dalam Memberantas Tindak Pidana Korupsi, hlm. 2.
} 
memang dianggap sebagai lembaga yang super power dengan tugas dan kewenangan yang dimiliki dalam independensi memberantas tindak pidana korupsi.

Di samping KPK terdapat Kejaksaan sebagai lembaga independen, karena tugas dalam pemberantasan tindak pidana korupsi hampir sama. Namun secara historis keberadaannya lebih dulu kejaksaan daripada KPK. Kemudian mengingat lembaga independen sifatnya sementara, maka jika suatu saat korupsi sudah mampu diberantas dapat diprediksi keberadaan KPK ditinjau ulang. ${ }^{3}$ Terlepas dari sifat independensi, perlu dikaji terkait kedudukan antara KPK dan Kejaksaan sebagai lembaga independen dalam memberantas tindak pidana korupsi ditinjau dari hukum tata negara. Analisa tentang permasalahan ini penting untuk mengetahui batasan-batasan kewenangan, tugas dan fungsi antara kedua lembaga tersebut dalam memberantas tindak pidana korupsi. Selanjutnya untuk apa inti dari analisa ini, tujuan utamanya sesuai dengan pembukaan bagian pendahuluan ini yakni menciptakan keteraturan dalam menjalankan ketatanegaraan yang berdasar pada konstitusi. Oleh sebab itu pada permasalahan ini perlu diteliti dalam bentuk penelitian hukum.

\section{METODE PENELITIAN}

Karya tulis ini berdasarkan hasil penelitian yang menggunakan tipe memandang hukum dari sudut pandang norma-normanya sehingga bersifat preskriptif. $^{4}$ Sedangkan pendekatan yang dipilih adalah pendekatan historis hukum, dalam implementasinya menguak histori dari Komisi Pemberantasan Korupsi (KPK) dan Kejaksaan agar dapat menjawab permasalahan yang diangkat dalam karya tulis ini.

\section{HASIL PENELITIAN DAN PEMBAHASAN Historis Komisi Pemberantasan Korupsi dan Kejaksaan}

3 Roy Saphely, Keberadaan Komisi Pemberantasan Korupsi Dalam Sistem Ketatanegaraan dan Implikasinya Terhadap Kewenangan Kejaksaan dan Kepolisian Republik Indonesia, Bagian Hukum PUPR Kabupaten Bandung, hlm. 81.

4 Depri Liber Sonata, Metode Penelitian Hukum Normatif dan Empiris : Karakteristik Khas dari Metode Meneliti Hukum, Jurnal Ilmu Hukum Fiat Justisia, Vol. 8 No. 1,2014, hlm. 25.

${ }^{5}$ M. Abdul Kholif AF, Eksistensi KPK dalam Peradilan Korupsi di Indonesia, Jurnal Hukum, Vol. 11 No. 26, 2004, hlm. 30.
Komisi Pemberantasan Korupsi (KPK) dibentuk melalui UU No. 30 Tahun 2002. Sebelum dibentuk komisi ini, Indonesia pada tahun 1995 berdasarkan riset yang dilakukan oleh Transparency Internasional (TI) berada dalam posisi pertama negara paling korup sedunia. Sedangkan pada tahun 1998 Indonesia turun berada di posisi keenam, ${ }^{5}$ melihat keadaan Indonesia yang sangat darurat maka memaksa untuk segera dilakukan reformasi. Tepat pada tahun 1998, Indonesia melalui pergerakan mahasiswa melengserkan Presiden kedua Soeharto dan menuntut dilakukan reformasi. Harapan yang ingin diwujudkan setelah reformasi adalah menurunnya tingkat korupsi di Indonesia. Akan tetapi pada tahun 2002 Indonesia tetap berada pada posisi keenam negara terkorut sedunia.

Keadaan tersebut yang melatarbelakangi dibentuknya Komisi Pemberantasan Korupsi (KPK). Sehingga pada tanggal 27 Desember 2002 DPR bersama dengan Pemerintah mengesahkan UU No. 30 Tahun 2002 tentang Komisi Pemberantasan Tindak Pidana Korupsi atau biasa disebut dengan Komisi Pemberantasan Korupsi (KPK). Undang-undang ini berperan untuk menambah dan melengkapi ketentuan yang telah ada pada UU No. 31 Tahun 1999 yang mana telah mengalami perubahan menjadi UU No, 20 Tahun 2001. Undang-Undang ini tidak hanya sebagai landasan hukum pembentukan KPK namun juga menjadi landasan hukum pembentukan Pengadilan Tindak Pidana Korupsi. ${ }^{6}$

Adapun menurut pandangan politik, alasan dibentuknya KPK yakni muncul faktor ketidakpercayaan masyarakat terhadap penegak hukum dalam menangani kasus tindak pidana korupsi. ${ }^{7}$ Sehingga dibutuhkan lembaga seperti KPK yang dapat memberantas tindak pidana korupsi yang mana ini juga menjadi salah satu semangat reformasi di bidang penegakan hukum.

${ }^{6}$ I Gusti Ayu Eviani Yuliantari, Pembentukan KPK Sebagai Lembaga Negara Khusus Dalam Pemberantasan Tindak Pidana Korupsi di Indonesia, Jurnal Hukum Undiknas, Vol. 2 No. 2, 2015, hlm. 175.

${ }^{7}$ Moh. Mahfud MD, Politik Hukum di Indoensia, Pustaka LP3ES Indonesia, Jakarta, 1998, hlm. 7. Dikutip oleh I Nyoman Ngurah Suwarnatha, Penguatan Eksistensi Lembaga Komisi Pemberantasan Korupsi dalam UndangUndang Dasar 1945, Jurnal Konstitusi, Vol. 2 No. 1, 2012, hlm. 29. 
Kemudian dari sudut pandang politik ini dapat diketahui bahwa KPK dibentuk berdasarkan kondisi dan situasi politik. Perspektif ini menjadi tepat saat dihadapkan dengan kenyataan bahwa hukum merupakan produk politik, jadi politik penting untuk mengambil suatu perubahan atau langkah hukum.

Dari lingkup internasional, Indonesia juga telah meratifikasi United Nations Convention Against Corruption (UNICAC). Konvensi PBB ini dibentuk pada tahun 2003, selanjutnya oleh Indonesia diratifikasi melalui UU No. 7 Tahun 2006. ${ }^{8}$ Dari peratifikasian ini maka Indonesia mengakui dan memiliki Konvensi PBB tersebut dalam upaya pemberantasan tindak pidana korupsi. Kemudian berada pada titik temu yang mana KPK sebagai lembaga baru dibentuk atas dasar yang kuat baik dari pertimbangan politik dalam negeri, hukum, dan kondisi negara Indonesia saat itu sebagai negara terkorup.

Kemudian jika ditinjau dari tugas dan kewenangannya, memang dapat dikatakan bahwa KPK sebagai lembaga yang super body. Artinya bahwa kewenangan dalam penyelidikan, penyidikan dan penuntutan sangat besar, sehingga harapannya peran KPK dalam pemberantasan tindak pidana korupsi juga sangat besar. Peran dari KPK dapat tergambar dari tugas dan kewenangan yang dimiliki, antara lain : koordinasi dengan instansi lain yang berkewenangan melakukan pemberantasan tindak pidana korupsi, melakukan supervise kepada instansi lain yang berkewenangan melakukan pemberantasan tindak pidana korupsi, berkewenangan dalam hal penyelidikan, penyidikan, dan penuntutan tindak pidana korupsi, melakukan upaya pencegahan tindak pidana korupsi, monitoring penyelenggaraan pemerintahan negara. ${ }^{9}$

Seiring berjalannya tugas dan kewenangan yang dilakukan oleh KPK, DPR merasa perlu untuk melakukan perubahan pada UU No. 30 Tahun 2002. Keinginan ini juga dilatar belakangi oleh kondisi politik juga, yakni

177.

${ }^{8}$ I Gusti Ayu Eviani Yuliantari, Op.Cit. hlm.

${ }^{9}$ I Nyoman Ngurah Suwarnatha, Op.Cit, hlm. 30.

${ }^{10}$ Eka Martiana Wulansri, Politik Hukum

Perubahan Kedua UU KPK, Jurnal RechtsVinding, 2016, hlm. 2 .

${ }^{11}$ Yusril Izha Mahendra, Kedudukan Kejaksaan Agung dan Posisi Jaksa Agung dalam Sistem Presidensial adanya penilaian terhadap kinerja KPK selama ini yang dirasa kurang efektif, koordinasi yang kurang antar penegak hukum, adanya pelanggaran kode etik yang dilakukan pimpinan dan staf KPK, adanya ketidaksesuaian tugas dan kewenangan KPK dengan Hukum Acara Pidana, prosesur penyadapan dan tidak adanya pengawas KPK dalam menjalankan tugas dan kewenangannya. $^{10}$

Kemudian historis dari lembaga Kejaksaan, keberadaannya sudah ada sebelum kemerdekaan. Sejak Belanda menjajah Indonesia, banyak peraturan dan sistem kelembagaan yang dibawa dan diterapkan di Indonesia. Salah satu produknya yakni lembaga kejaksaan, yang mana dalam istilah Belanda menjadi Raad van Justisi. Kejaksaan pada masa koloni diatur di dalam Indische Staatsregeling dan memiliki kedudukan yang sama dengan Mahkamah Agung. ${ }^{11}$ Kedudukan Kejaksaan didasarkan pada UUD Negara Belanda, sehingga peran tugas kejaksaan didasarkan atas hukum Belanda.

Setelah kemerdekaan Indonesia, tepat pada tanggal 19 Agustus 1945 PPKI melalui rapat memutuskan kedudukan Kejaksaan berada dalam lingkungan Departemen Kehakiman. Sudah berjalan hampir 14 tahun setelah keputusan rapat PPKI, Presiden Soekarno mengeluarkan Dekrit Presiden 5 Juli 1959. Dampak dari Dekrit ini Soekarno ingin memusatkan kekuasaan di tangan Presiden atau sistem presidensial. Sehingga kelembagaan Kejaksaan ditata ulang dan tidak lagi berdasar pada tradisi kolonial Belanda namun dilandaskan pada UUD 1945. Oleh karena itu, Presiden Soekarno mengeluarkan Keputusan Presiden No. 204 Tahun 1960 menjelaskan bahwa kedudukan Kejaksaan tidak lagi menjadi satu lingkungan dengan Departemen Kehakiman dan Mahkamah Agung namun menjadi institusi yang berdiri sendiri serta menjadi bagian langsung dari kabinet. Dari sini dapat dipahami bahwa

di Bawah UUD 1945 sebagaimana dimuat di dalam Buku Muhammad Tahir Azhary, Beberapa Aspek Hukum Tata Negara, Hukum Pidana dan Hukum slam, Kencana Prenada Media Group, Jakarta, 2012, hlm. 4. Dikutip oleh Dio Ashar Wicaksana, Kedudukan Kejaksaan RI dalam Sistem Hukum Tata Negara Indonesia, Fiat Justitia, Vol. 1 No. 1, 2013, hlm. 4. 
kedudukan Kejaksaan tidak lagi berada dalam ranah yudikatif namun masuk pada eksekutif. ${ }^{12}$

Setahun setelah dikeluar Dekrit Presiden 5 Juli 1959, DPR bersama dengan Pemerintah mengesahkan UU No. 15 Tahun 1961 tentang Pokok-Pokok Kejaksaan RI. Pada undangundang tersebut, Kejaksakan disebut sebagai alat negara yang berperan sebagai penegak hukum dan alat revolusi yang memiliki tugas sebagai Penuntut Umum. ${ }^{13}$ Perubahan kelembagaan Kejaksaan kembali dilakukan saat Soeharto menggantikan Soekarno sebagai Presiden RI, yang mana perubahan tetap dilakukan walaupun UU No. 15 Tahun 1961 masih tetap berlaku. Perubahan yang terjadi yakni kelembagaan Kejaksaan disebut sebagai Kejaksaan Agung dan dipimpin oleh seorang Jaksa Agung yang kedudukannya setara dengan menteri,

Pada tahun 1991 UU No. 5 Tahun 1991 tentang Kejaksaan Republik Indonesia. Undangundang ini menjelaskan bahwa Kejaksaan merupakan lembaga pemerintahan yang memiliki kewenangan dalam bidang penuntutan di tatanan susunan kekuasan penegak hukum serta keadilan. Kedudukan Kejaksaan juga mengalami perubahan yang sebelumnya sebagai alat negara menjadi lembaga pemerintahan. Selanjutnya Undang-Undang ini tidak diberlakukan lagi dan diganti dengan UU No. 16 Tahun 2004. Perubahan tampak pada konsideran yang menegaskan bahwa Kejaksaan memiliki fungsi dalam kekuasan kehakiman namun kedudukan dan perannya masih tetap sebagai lembaga pemerintahan yang berkewenangan melakukan penuntutan yang bebas dari intervensi pihak manapun. Sampai saat penelitian ini dilakukan, undang-undang ini masih diberlakukan.

Setelah memahami uraian sejarah Komisi Pemberantasan Korupsi (KPK) dan Kejaksaan Republik Indonesia, maka dapat dimengerti bahwa kedua lembaga ini adalah lembaga yang independen dan sangat dimungkinkan akan sering mengalami perubahan pengaturan kedudukan, kelembagaan, peran maupun fungsinya. Perubahan yang sudah terjadi atau

${ }^{12}$ Antonius, Tugas dan Kedudukan Lembaga Kejaksaan Sebagai Pelaksana Kekuasaan Penuntutan dalam Sistem Pemerintahan Predsidensial Berdasarkan Undang-Undang Nomor 16 Tahun 2004 Tentang Kejaksaan Republik Indonesia, hlm. 5.

${ }^{13}$ Dio Ashar Wicaksana, Op.Cit. hlm. 5. akan terjadi akan berdampak munculnya tumpang tindih suatu kedudukan maupun peran dalam penanganan tindak pidana korupsi. Sebab kedua lembaga ini memiliki peran yang sama dalam upaya pemberantasan tindak pidana korupsi. Namun diperlukan batasan-batasan yang pasti antara kedua lembaga ini, sehingga pembahasan selanjutnya akan membahasan independensi dari KPK dan Kejaksaan yang berkaitan dengan kedudukannya dalam sistem ketatanegaraan.

\section{KEDUDUKAN KPK DAN KEJAKSAAN SEBAGAI LEMBAGA INDEPENDEN}

\section{Konsep independen menurut Artidjo} Alkostar memiliki dua makna yakni independensi institusional atau kelembagaan dan independensi fungsional. Independensi insitusional merupakan sifat mandiri yang dimiliki oleh suatu lembaga sehingga harus memiliki kebebasan dan kemerdekaan dari intervensi pihak manapun. Sedangkan yang dimaksud dengan independensi fungsional merupakan sifat mandiri dalam menjalankan fungsi dan tugas suatu lembaga. ${ }^{14}$

Adapun yang dikategorikan sbagai alat perlengkapan negara, yakni : o tambahan, , instansi , komisi-komisi negara, dan badan-badan independen. Sedangkan yang dimaksud dengan organ negara penunjang memiliki sifat independen yang biasa disebut dengan komisi independen atau lembaga negara independen. Kemudian pengertian komisi negara independen yakni suatu organ negara yang secara kelembagaan dan fungsi memiliki sifat independen sehingga kekuasaannya diluar dari eksekutif, legislatif dan yudikatif. Sehingga komisi negara biasa berbeda dengan komisi negara independen. ${ }^{15}$

Pasca pengesahan UU No. 19 Tahun 2019 sebagai peruabahan dari UU No. 30 Tahun 2002, kedudukan KPK sebagai lembaga negara dipertegas masuk pada rumpun kekuasaan eksekutif namun tetap memiliki sifat independen

\footnotetext{
${ }^{14}$ Ari Wibowo, Independensi Kejaksaan Dalam Sistem Peradilan Pidana Indonesia, Universitas Islam Indonesia Yogyakarta, hlm. 4.

15 Nehru Asyikin dan Adam Setiawan, Kedudukan KPK dalam Sistem Ketatanegaraan Pasca Diterbitkan Revisi Undang-Undang KPK, Vol. 4 No. 1, 2020, hlm. 133.
} 
dalam menjalankan tugas dan kewenangannya. ${ }^{16}$ Dengan demikian KPK dapat dikategorikan sebagai lembaga negara yang bersifat independensi fungsional sedangkan secara kelembagaan masuk dalam kekuasaan eksekutif. Dari uraian sedikit tentang komisi negara independen maka KPK berdasarkan UU No. 19 Tahun 2019 bukan merupakan komisi negara independen namun hanya sebagai komisi negara biasa.

Dalam revisi UU KPK terdapat Dewan Pengawas KPK, salah satu tugasnya adalah mengawasi KPK dalam melaksanakan tugas dan wewenang. Dengan hadirnya dewan ini maka mempertegas bahwa KPK merupakan komisi negara biasa yang dalam pelaksanaan tugas dan wewenang membutuhkan pengawasan agar tidak terjadi penyelewengan atas sifat independensi yang dimiliki.

Sedangkan dalam kelembagaan Kejaksaan, sifat independen yang dimiliki juga hampir sama dengan KPK. Berdasarkan struktur kelembagaan Kejaksaan masuk menjadi bagian dari eksekutif atau pemerintah, namun dalam pelaksanaan tugas dan wewenangnya sebagai penegak hukum khususnya dalam penuntutan maka Kejaksaan dituntut untuk independen. John Mc Kechnie mengemukakan pendapatnya bahwa Kejaksaan merupakan institusi yang rawan dipengaruhi atau diintervensi oleh pihak eksekutif dan legislatif. Apabila kedua kekuasaan ini ingin menghancurkan Kejaksaan, dengan mudah melakukannya sebab legislatiif dapat bermain dalam perumusan undang-undang sedangkan eksekutif dapat bermain dalam wilayah administrasi. ${ }^{17}$

Kejaksaan dapat juga disebut sebagai kuasa hukum dari Kepolisian sebab diberi kewenangan untuk menjelaskan hasil penyidikan Kepolisian di Pengadilan. Selain itu Kejaksaan juga menjadi konsultan hukum apabila Kepolisian membutuhkan nasehat hukum dalam prosedur penegakan hukum. selanjutnya dalam kedudukannya sebagai penuntut umum, jaksa menerapkan hukum yang berlaku dalam suau kasus melalui penuntutan. Melihat dari tugas dan kewenangan Kejaksaan tersebut, maka timbul dilema apakah dalam penegakan hukum masuk hlm. 138.

${ }^{16}$ Nehru Asyikin dan Adam Setiawan, Op.Cit,

${ }^{17}$ Ari Wibowo, Op.Cit, hlm. 7.

${ }^{18}$ Ratna Sari Dewi Polontalo, Independensi Jaksa Sebagai Penuntut Umum dalam Tindak Pidana dalam kekuasaan kehakiman atau bahkan sebagai badan public dalam melaksanakan tugas eksekutif.

Dalam undang-undang pembentuknya, Kejaksaan sebagai penuntut umum harus merdeka dan lepas dari kekuasaan pemerintah maupun pengaruh lain. Hal ini didasari Pasal 37 ayat (1) menegaskan bahwa Jaksa Agung bertanggungjawab atas penuntutan yang sesuai dengan independensi demi keadilan berdasarkan hukum dan hati nurani. Sehingga susunan kelembagaan kejaksaan pidana Kejaksaan merupakan lembaga negara yang memiliki istilah sebagi Kejaksaan Republik Indonesia. pimpinan dari Kejaksaan Republik Indonesia disebut sebagai Jaksa Agung. Sehingga peran dari Jaksa Agung dalam mengednalikan kebijakan penegakan hukum dan keadilan sangat penting, maka pola yang digunakan adalah sentralistik yang mana seluruh jaksa di seluruh Indonesia berpusat pada kewenangan Jaksa Agung. 18 Sehingga juga dapat diketahui dari pola sentralistik maka setiap jaksa juga tidak memiliki independensi yang murni seperti independensi hakim, jaksa harus mengkoordinasikan dan mengacu kepada atasannya dalam proses penegakan hukum khususnya penuntutan.

\section{PENUTUP}

Sejarah terbentuknya Komisi Pemberantasan Korupsi (KPK) dimulai setelah disahkannya UU No. 30 Tahun 2002. Pembentukan KPK didasari atas kondisi Indonesia pada tahun 1995 sebagai negara paling korup sedunia. Kemudian ada keadaan politik yang menganggap bahwa ada faktor ketidakpercayaan masyarakat terhadap penegak hukum dalam menangani kasus tindak pidana korupsi. Sehingga pemerintah dan DPR membuat Undang-Undang Komisi Pemberantasan Tindak Pidana Korupsi atau biasa disebut sebagai KPK. Sedangkan sejarah terbentuknya Kejaksaan sudah ada sejak zaman kolonial Belanda menjajah Indonesia. sehingga pasca proklamasi kemerdekaan Indonesia, PPKI melalui rapat anggota memutuskan kedudukan Kejaksaan berada dalam lingkungan Departemen Kehakiman. Namun setelah mengalami beberapa kali perubahan kedudukan maupun undang-

Korupsi Menurut Undang-Undang Nomor 16 Tahun 2004 Tentang Kejaksaan Republik Indoneisa, Lex Crimen, Vol. 7 No, 6, 2018, hlm. 37. 
undang tentang Kejaksaan, akhirnya UU No. 16 Tahun 2004 disahkan dan digunakan sampai saat penelitian ini dibuat.

Kedudukan KPK berdasarkan UU No. 16 Tahun 2019, dianggap sebagai lembaga negara yang menjadi satu rumpun dengan kekuasaan eksekutif dan bersifat independen dalam melaksanakan tugas dan kewenangannya. Sehingga KPK merupakan komisi negara biasa atau sebagai lembaga negara penjuang. Adapun Kejaksaan juga memiliki kedudukan yang hampir sama dengan KPK, dimana dalam menjalankan tugas dan kewenangan penegakan hukum bersifat independen namun dalam kelembagaan menjadi satu dengan kekuasaan eksekutif. Sehingga dapat dikatakan kedua lembaga ini memiliki sifat independensi fungsional.

Saran yang ditawarkan dalam penelitian ini adalah bagi pemerintah dan DPR hendaknya dalam membentuk atau mengesahkan peraturan perundang-undangan yang menyangkut kedudukan suatu lembaga harus jelas dan tegas tujuan yang ingin dicapai dalam pembentukan lembaga. Jika ingin mewujudkan keadilan dalam penegakan hukum khsususnya tindak pidana korupsi maka bagi KPK maupun Kejaksaan harus diberi sifat independensi yang murni agar dapat menegakkan keadilan. Sebab jika kedua lembaga ini independensi tidak diatur secara jelas maka akan mengakibatkan tumpang tindih tugas dan wewenang pemberantasan tindak pidana korupsi.

\section{DAFTAR PUSTAKA}

Antonius, Tugas dan Kedudukan Lembaga Kejaksaan Sebagai Pelaksana Kekuasaan

Penuntutan dalam Sistem Pemerintahan Presidensial Berdasarkan Undang-Undang Nomor 16 Tahun 2004 Tentang Kejaksaan Republik Indonesia. Dalam Sistem Peradilan Pidana Indonesia, Universitas Islam Indonesia Yogyakarta.

Bintara Sura Priambada, Eksistensi KPK Dalam Memberantas Tindak Pidana Korupsi.

Depri Liber Sonata, Metode Penelitian Hukum Normatif dan Empiris : Karakteristik Khas dari Metode Meneliti Hukum, Jurnal Ilmu Hukum Fiat Justisia, Vol. 8 No. 1,2014.
Dio Ashar Wicaksana, Kedudukan Kejaksaan RI dalam Sistem Hukum Tata Negara Indonesia, Fiat Justitia, Vol. 1 No. 1, 2013.

Eka Martiana Wulansri, Politik Hukum Perubahan Kedua UU KPK, Jurnal RechtsVinding, 2016.

Hendra Nurtjahjo, Lembaga, Badan, dan Komisi Negara Independen (State Auxiliary

Agencies) di Indonesia: Tinjauan Hukum

Tata Negara, Jurnal Hukum dan Pembangunan, Vol. 35 No. 3, 2005.

I Gusti Ayu Eviani Yuliantari, Pembentukan KPK Sebagai Lembaga Negara Khusus Dalam

Pemberantasan Tindak Pidana Korupsi di Indonesia, Jurnal Hukum Undiknas, Vol. 2 No. 2, 2015.

I Nyoman Ngurah Suwarnatha, Penguatan Eksistensi Lembaga Komisi Pemberantasan

Korupsi dalam Undang-Undang Dasar 1945, Jurnal Konstitusi, Vol. 2 No. 1, 2012.

M. Abdul Kholif AF, Eksistensi KPK dalam Peradilan Korupsi di Indonesia, Jurnal Hukum, Vol. 11 No. 26, 2004.

Nehru Asyikin dan Adam Setiawan, Kedudukan KPK dalam Sistem Ketatanegaraan Pasca

Diterbitkan Revisi Undang-Undang KPK, Vol. 4 No. 1, 2020.

Ratna Sari Dewi Polontalo, Independensi Jaksa Sebagai Penuntut Umum dalam Tindak

Pidana Korupsi Menurut UndangUndang Nomor 16 Tahun 2004 Tentang Kejaksaan Republik Indoneisa, Lex Crimen, Vol. 7 No, 6, 2018.

Roy Saphely, Keberadaan Komisi Pemberantasan Korupsi Dalam Sistem Ketatanegaraan dan

Implikasinya Terhadap Kewenangan Kejaksaan dan Kepolisian Republik Indonesia, Bagian Hukum PUPR Kabupaten 